\title{
Secondary Growth Control in Garlic With Post Emergency Herbicides
}

\author{
Rodrigo P. de Assis ${ }^{1}$, Douglas C. de Souza ${ }^{1}$, Valter C. de A. Júnior ${ }^{1}$, Adenilson H. Gonçalves ${ }^{1}$ \\ \& Rovilson J. de Souza ${ }^{1}$ \\ ${ }^{1}$ Universidade Federal de Lavras, Lavras, MG, Brazil \\ Correspondence: Douglas C. de Souza, Universidade Federal de Lavras, Campus Universitário, 37200-000, \\ Lavras, MG, Brazil. Tel: 55-359-9113-6312. E-mail: douglascorrea@ymail.com
}

\begin{tabular}{|c|c|c|}
\hline 019 & : March 31, 2019 & Published: May 31, 2019 \\
\hline doi:10.5539/jas & $\mathrm{U}$ & v11n7p67 \\
\hline
\end{tabular}

\begin{abstract}
This study aimed to verify the effect of the herbicides in the secondary growth control, productivity, and quality in garlic. The treatments were 5 herbicides: Glyphosate; Etoxissulfurom; 2-nicotinic acid; Halossulfurom and Metsulfurom-methyl and 5 doses $(0 ; 10 ; 15 ; 20$ and $25 \%$ of the smallest dose recommended for control of the weed). The experimental design was a randomized block, with 3 repetitions. The following evaluations were made: the total and marketable yield of bulbs, a percentage of secondary growth in bulbs, the medium mass of commercial bulbs and the number of bulbils per bulb of the commercial production. Larger productivities total and marketable was observed for the herbicide Glyphosate, $13.93 \mathrm{t} \mathrm{ha}^{-1}$, and $13.16 \mathrm{t} \mathrm{ha}^{-1}$, with doses of $10.81 \%$ and $13.12 \%$ of the commercial dose, respectively. The smallest incidence of secondary growth $4.05 \%$ was observed for Glyphosate with $15.58 \%$ of the dose. The largest medium mass of commercial bulbs $35.75 \mathrm{~g}$ were observed for the herbicide Glyphosate with $15.83 \%$ of the dose. The herbicides 2-nicotínic acid and Metsulfurom-methyl reduced the total productivity in relation to the control treatment without herbicide application and they promoted little gain in commercial productivity. Some herbicides can control the secondary growth in vernalized garlic, however, are necessary appropriate doses applied 50 days after the planting.
\end{abstract}

Keywords: Allium sativum L., stress, quality, productivity

\section{Introduction}

Garlic (Allium sativum L.) is a vegetable of great economic and social importance, being cultivated mainly by small producers, generating jobs due to the need for labor. In 2017 Brazilian production reached 126,157 tons, of which 84,131 tons were exported (Agrianual, 2018).

Among the cultural aspects involved in the production of noble garlic, irrigation management has shown great prominence in Brazilian research, since this is directly related to the increase of crop productivity and the occurrence of secondary growth (Resende et al., 2004). Secondary growth is characterized by excessive bulb formation, with reduced size and low acceptance by the consumer market (Souza \& Macedo, 2009). Several factors have been related to this anomaly, such as photoperiod (Park \& Lee, 1979), temperature (Souza \& Casali, 1986), cultivar (Souza \& Macedo, 2009), nitrogen (Trani et al., 2008), irrigation (Marouelli et al., 2002), vernalization (Wu et al., 2015; Qaryouti \& Kasrawi, 1995), gibberellins (Vieira et al., 2014; Argüello et al., 1991) and mulching (Trani et al., 2008).

For better bulbification and control of the secondary growth, water stress must be performed during the period of differentiation of bulbils (Macedo et al., 2009). Plant stress induces the formation of abscisic acid, which is the hormone related to solutes translocation, opening and closing of stomata and has an antagonistic effect on gibberellins (Taiz et al., 2017). According to Vieira et al. (2014) the formation of abscisic acid is directly linked to the good formation of garlic bulbs. While the gibberellins produced during the vernalization are linked to the differentiation of the bulbils and the secondary growth of garlic (Liu et al., 2019). In regions where rainfall occurs in the winter, especially in the Center-South of the state of Paraná in Brazil, for example, the process of control of the vegetation with water stress is often not fully efficient (Resende et al., 2013).

Among the herbicides most used in agriculture, glyphosate and sulfonylureas are distinguished by the broad spectrum of weed control and low dosage efficiency, respectively. Being widely used in areas of vegetable production (Novo \& Miranda Filho, 2006). The different chemical groups of the herbicides currently used have action on the metabolic pathways by decreasing or inhibiting the production of precursor compounds of 
important molecules for the metabolism of plants, such as hormones, chlorophylls among others (SALMAZO, 2009). Due to the great action of herbicides on plant physiology, its use may be an alternative to water stress in garlic culture. In view of the above, this work had as objective to verify the effect of herbicides on the control of secondary growth, productivity and quality of the bulbs in vernalized garlic.

\section{Materials and Methods}

The experiment was conducted from May to December 2015, in the experimental area of the Department of Agriculture of the Federal University of Lavras (UFLA), in the city of Lavras, South of the State of Minas Gerais in Brazil, located at $21^{\circ} 14^{\prime} \mathrm{S}$ latitude, longitude $45^{\circ} 00^{\prime} \mathrm{W}$ and altitude of $918.8 \mathrm{~m}$. The climate of the region according to the climatic classification of Köppen is $\mathrm{Cwb}$, with dry winter and rainy summer (Álvares et al., 2013).

The treatments consisted of five herbicides: Glyphosate $\left(360 \mathrm{~g} \mathrm{~L}^{-1}\right)$; Ethoxysulfuron $\left(600 \mathrm{~g} \mathrm{~kg}^{-1}\right)$; 2-nicotinic acid $\left(25 \mathrm{~g} \mathrm{~L}^{-1}\right)$; Halosulfuron-methyl $\left(750 \mathrm{~g} \mathrm{~kg}^{-1}\right)$ and Metsulfuron-methyl $\left(600 \mathrm{~g} \mathrm{~kg}^{-1}\right)$, and five doses $(0,10,15,20$ and $25 \%$ of the lowest recommended dose for weed control). The cultivar "Quitéria" from meristems culture was used, multiplied with anti-aphid. The experimental design was a randomized block design, with three replications. The plots were arranged in beds and composed of six rows arranged in double rows. The spacing between double rows was $37 \mathrm{~cm}$ and the spacing between single rows of $12 \mathrm{~cm}$. The planting density was 10 bulbs per linear meter. The useful area was defined by the four central rows, subtracting still $0.2 \mathrm{~m}$ at the ends of the plot.

The soil of the experimental area is classified as a Red Latosol Distroferric and has the following characteristics in the arable layer from 0 to $20 \mathrm{~cm}: \mathrm{pH}\left(\right.$ in $\left.\mathrm{H}_{2} \mathrm{O}\right)=6.1$; Al exchangeable $=0.10 \mathrm{cmol}_{\mathrm{c}} \mathrm{dm}^{-3} ; \mathrm{Ca}^{2+}=1.8 \mathrm{~cm}^{3} \mathrm{dm}^{-3}$; $\mathrm{Mg}^{2+}=0.6 \mathrm{cmol}_{\mathrm{c}} \mathrm{dm}^{-3} ; \mathrm{P}-$ Mehlich $=2.6 \mathrm{mg} \mathrm{dm}^{-3} ; \mathrm{K}^{+}=50 \mathrm{mg} \mathrm{dm}^{-3} ;$ Organic matter $=2.61$ dag $\mathrm{Kg}^{-1} ; \mathrm{V}=54.84$; Sum of bases $=2.53 \mathrm{cmol}_{\mathrm{c}} \mathrm{dm}^{-3} ; \mathrm{CTC}=4.61 \mathrm{cmol}_{\mathrm{c}} \mathrm{dm}^{-3} ; \mathrm{Zn}^{2+}=1.22 \mathrm{mg} \mathrm{dm} ; \mathrm{Fe}^{2+}=69.81 \mathrm{mg} \mathrm{dm}{ }^{-3} ; \mathrm{Mn}^{2+}=$ $17.49 \mathrm{mg} \mathrm{dm}^{-3} ; \mathrm{Cu}^{2+}=0.64 \mathrm{mg} \mathrm{dm}^{-3} ; \mathrm{B}=0.43 \mathrm{mg} \mathrm{dm}^{-3} ; \mathrm{S}=6.63 \mathrm{mg} \mathrm{dm}^{-3}$; Soil texture = Argilose.

Liming and fertilization were performed according to Souza and Macedo (2009) and the Soil Fertility Commission of the State of Minas Gerais (1999), recommended for garlic cultivation based on soil analysis, to raise soil saturation to $70 \%$. Planting fertilization consisted of $20 \mathrm{~kg} \mathrm{ha}^{-1}$ of N, $200 \mathrm{~kg} \mathrm{ha}^{-1}$ of $\mathrm{P}_{2} \mathrm{O}_{5}, 60 \mathrm{~kg} \mathrm{ha}^{-1}$ of $\mathrm{K}_{2} \mathrm{O}, 4.5 \mathrm{~kg} \mathrm{ha}^{-1}$ of $\mathrm{Mg}, 3 \mathrm{~kg} \mathrm{ha}^{-1}$ of $\mathrm{B}$ and $3 \mathrm{~kg} \mathrm{ha}^{-1}$ of $\mathrm{Zn}$, using sources of magnesium sulfate, borax, and zinc sulfate, respectively. In the cover, $105 \mathrm{~kg} \mathrm{ha}^{-1}$ of $\mathrm{N}$ was applied, being divided into two plots at 30 and 75 days after planting, with a distribution of 30 and $75 \mathrm{~kg} \mathrm{ha}^{-1}$, respectively, using urea as the source.

The seed bulbs were submitted to a 50 day vernalization period in a cold chamber with a mean temperature of $4^{\circ} \mathrm{C}$. Herbicide doses were applied 50 days after planting during the stage of bulb differentiation.

Cultural and phytosanitary treatments, as well as other crop care, were carried out in accordance with regional needs and recommendations for garlic. Irrigation was done by means of conventional sprinkling at two-day intervals and was suspended 10 days before harvest, aiming at better postharvest conservation of the bulbs.

Harvesting was carried out during the senescence phase of the plants when they had only three green leaves at the beginning of drying and a vegetative cycle of 125 days. After harvest, the plants were sun-dried for five days and cured in the shade for 60 days. After the curing, the bulb toilet (removal of the straw and roots of the bulbs) was carried out, and the production data were recorded. The following evaluations were performed: total bulb productivity, the percentage of bulb bulbs, commercial bulb yield, average commercial bulb mass, number of bulbs per bulb of commercial production.

Statistical analyses were performed with the aid of statistical software Sisvar ${ }^{\circledR}$ (Ferreira, 2011), using a regression analysis at 5\% probability for the interaction between doses and herbicides.

\section{Results and Discussion}

The herbicides Halosulfuron and Ethoxysulfuron were very aggressive to the garlic, causing the death of all the plants even in the lower doses. For total production, commercial production, a percentage of secondary growth of bulbs and the average mass of commercial bulbs there was an interaction $(p<0.05)$ as a function of herbicides and doses. There was no significant effect on the number of commercial bulb bulbs in relation to the application of herbicides and doses.

There was a quadratic effect $(\mathrm{p}<0.05)$ for total and commercial productivity in the interaction of herbicides and doses. Higher commercial and total yields were observed for the herbicide Glyphosate, $13.93 \mathrm{t} \mathrm{ha}^{-1}$ and $13.16 \mathrm{t}$ $\mathrm{ha}^{-1}$, with the doses of $10.81 \%$ and $13.12 \%$ of the commercial dose, respectively (Figures 1 and 2 ). 




Figure 1. Total productivity in $\mathrm{tha}^{-1}$ as a function of sub-doses of herbicides applied in post-emergence in garlic

The herbicides 2-nicotinic acid and Metsulfuron-methyl reduced total productivity over the control (without herbicide application) and promoted little gain in commercial productivity. Although not causing the death of plants, similar to the other sulfonylureas used in the work, the damage caused by these herbicides restricted the growth and as a consequence the formation of bulbs.

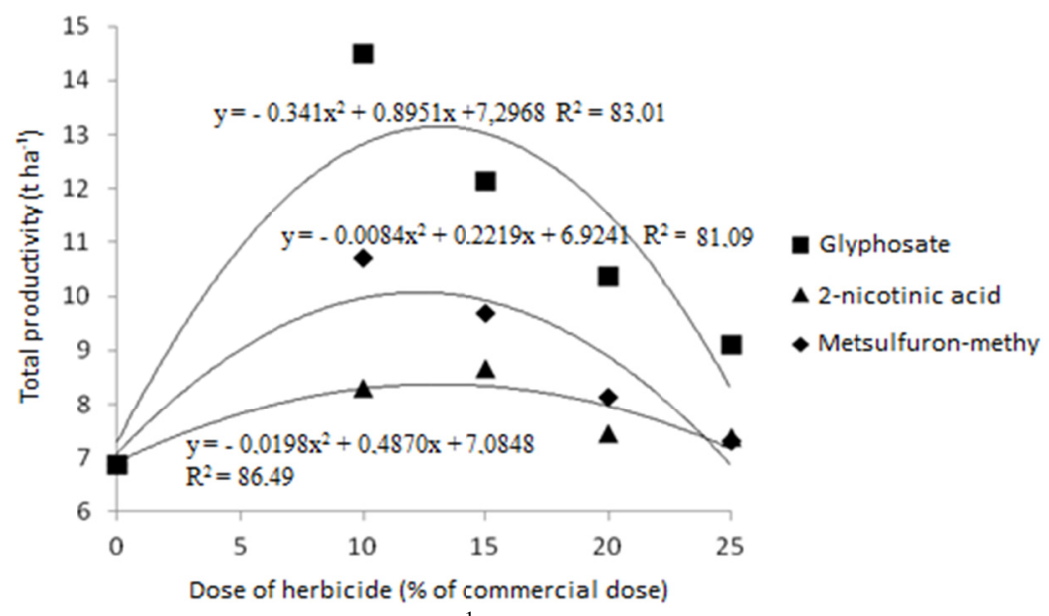

Figure 2. Commercial productivity in $\mathrm{tha}^{-1}$ as a function of sub-doses of herbicides applied in post-emergence in garlic

Fernandes et al. (2010) observed total and commercial yields of $9.1 \mathrm{t} \mathrm{ha}^{-1}$ and $9.0 \mathrm{tha}^{-1}$, respectively, using garlic obtained through meristem culture and multiplied under conditions of anti-aphidic weaving. Macedo et al. (2006) obtained total and commercial yields of $11.91 \mathrm{t} \mathrm{ha}^{-1}$ and $10.25 \mathrm{t} \mathrm{ha}^{-1}$ in a study on periods and times of water stress. Resende et al. (2001), using the anti-gibberellinic paclobutrazol observed productivity of $6.88 \mathrm{t} \mathrm{ha}^{-1}$, causing a great reduction in the number of leaves and height of plants in the field, and consequently low productivity, besides being a product with long residual effect in the soil and great toxicity. Resende et al. (2013) observed low total and commercial yields, $3.3 \mathrm{t} \mathrm{ha}^{-1}$, and $1.7 \mathrm{t} \mathrm{ha}^{-1}$, respectively, using the cultivar "Quitéria" in the Center-South region of Paraná, but it is not possible to perform water stress in the region due to winter rains, causing great losses in quality and productivity. It is observed the great importance of the stress in garlic plants for the bulbification and filling of the bulbs comparing if the works in the literature.

Some works have been demonstrating the potential of the use of underdoses of herbicides, as the glyphosate, they be intentionally applied in the plants as method to alter the balance of some specific metabolic processes seeking benefits in the growth and/or productivity of the cultures. Olesen and Cedergreen (2010) relate that lower doses of Glyphosate they can increase the photosynthesis rate and sugar production. Velini et al. (2008) studied the effect of underdoses of Glyphosate in species of plants (soy, eucalyptus, pine tree and corn), and 
concluded that all the studied species presented increase in the growth. The increase in the production of photo-assimilates for the herbicide underdoses associated to the production of abscisic acid caused by the stress might have increased the production of bulbs in garlic.

There was a quadratic effect $(\mathrm{p}<0.05)$ for percentage of secondary growth bulbs in the interaction of herbicides and doses. The lowest incidence of $4.05 \%$ was observed at the dose of $15.58 \%$ of the commercial dose of Glyphosate, according to Figure 3. For the herbicide Metssulfuron-methyl, a 7.61\% for the dose of $15.89 \%$ of the commercial dose, however there was a reduction in the productivity and size of the bulbs. The herbicide 2-nicotinic acid was not efficient in the control of secondary growth with $20.48 \%$ of secondary growth for the best dose. For the control without herbicide application and with recommended irrigation during the whole cycle, there was more than $35 \%$ of secondary growth, which indicates that stress is necessary for the production of bulbs with quality and without secondary growth.

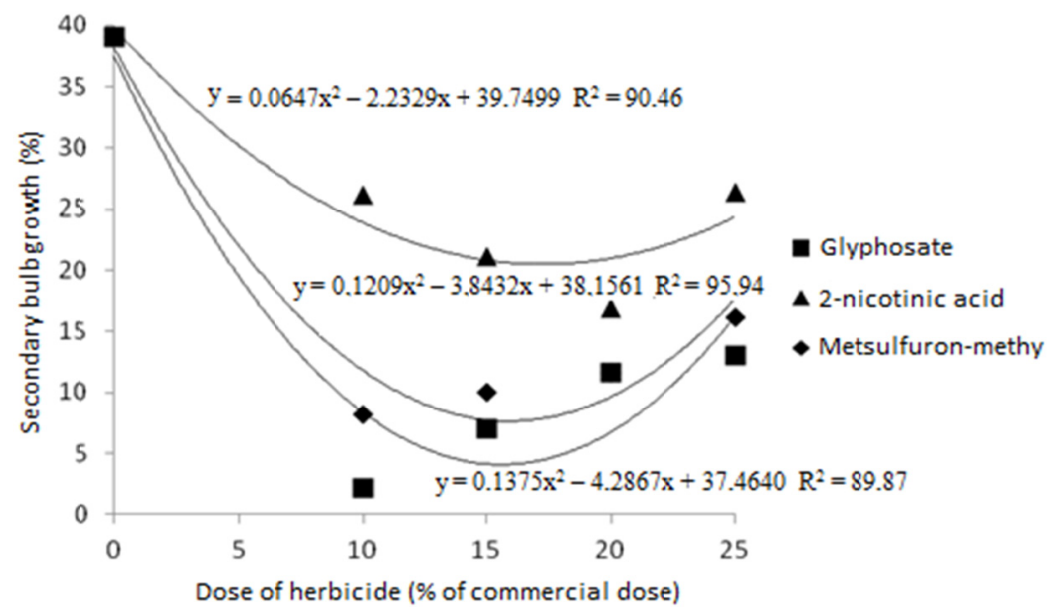

Figure 3. Percentage of secondary growth bulbs as a function of sub-doses of herbicides applied in post-emergence in garlic

According to Macedo et al. (2006), the method of control of secondary growth with water stress showed a linear reduction in the percentage of secondary growth bulbs, reaching about $4 \%$ of the incidence of this anomaly with 20 days without irrigation from 55 days after planting. For regions where rainy winter does not occur, this method is the most adequate, being efficient in the control of secondary growth and guaranteeing high productivities. Resende et al. (2013) obtained 26.6\% of supercharging for the cultivar "Quitéria" when no stress method was used in the control of the secondary growth, however in the same work, some cultivars showed more than $90 \%$ of secondary growth. Herbicide control can vary depending on climatic and application conditions, although it has presented good results, it is necessary to carry out larger studies in different regions and with different doses and mechanisms of action. The efficiency of both glyphosate and Metsulfuron-methyl is observed in the control of secondary growth gradation when applied in low doses and may be a viable alternative to water stress.

There was a quadratic effect $(p<0.05)$ for the average mass of commercial bulbs in the interaction of herbicides and doses. The highest mean mass of commercial bulbs of $35.75 \mathrm{~g}$ was observed at the dose of $15.83 \%$ of the commercial dose of glyphosate (Figure 4). Doses above $15 \%$ of the commercial dose reduced the average mass of the commercial bulbs and increased the incidence of secondary growth, causing direct losses in quality and productivity for all tested herbicides. 


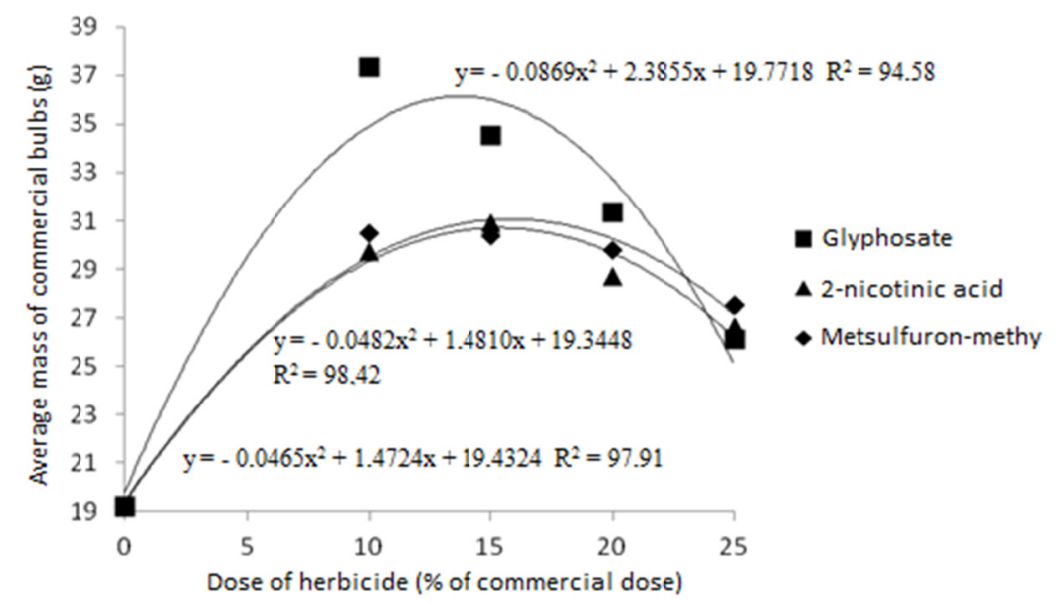

Figure 4. The average mass of commercial bulbs in grams as a function of sub-doses of herbicides applied in post-emergence in garlic

Macedo et al. (2006) observed a linear increase in the average mass of commercial bulbs with the increase of the water stress period up to 20 days. With water stress, a higher stock of assimilates occurs in subterranean organs such as rhizomes, tubers, and bulbs, in relation to the aerial part, and the greater the exposure to the water deficit, the greater the favoring to the accumulation of assimilates in these organs (Taiz et al., 2017). It is observed that the effect of the herbicides also promoted the translocation of assimilates to the bulbs since there was an increase in the average mass of commercial bulbs.

\section{Conclusion}

Some herbicides can control secondary growth the vegetation on vernalized garlic, however, adequate doses applied 50 days after planting are necessary.

\section{Acknowledgements}

The authores thank the Fundação de Apoio à Pesquisa de Minas Gerais (FAPEMIG), the Coordenação de Aperfeiçoamento de Pessoal de Nível Superior (CAPES), and the Conselho Nacional de Desenvolvimento Científica e Tecnológico (CNPq), for financial support and scholarships.

\section{References}

Agrianual. (2018). Anuário da agricultura Brasileira. Agrobusiness intelligence. IEG/FNP.

Álvares, C. A., Stape, J. L., Sentelhas, P. C., Goncalves, J. L. M., \& Sparovek, G. (2013). Koppen's climate classification map for Brazil. Meteorologische Zeitschrift, 22, 711-728. https://doi.org/10.1127/09412948/2013/0507

Arguello, J., Ledesma, A., \& Bottini, R. (1991). Hormonal regulation of dormancy in garlic (Allium sativum L.) cv Rosado Paraguayo. Agriscientia, 8, 9-14.

CFSEMG (Comissão de Fertilidade do Solo de Minas Gerais). (1999). Recomendações para o uso de fertilizantes e corretivos em Minas Gerais ( $5^{\mathrm{a}}$ aproximação, p. 359). Viçosa: CFSEMG.

Fernandes, L. J. C., Büll, L. T., Corrêa, J. C., Pavan, M. A., \& Imaizumi, I. (2010). Resposta de plantas de alho livres de vírus ao nitrogênio em ambiente protegido. Horticultura Brasileira, 28, 97-101. https://doi.org/ $10.1590 / \mathrm{S} 0102-05362010000100018$

Ferreira, D. F. (2011). Sisvar: A computer statistical analysis system. Ciência e Agrotecnologia, 35, 1039-1042. https://doi.org/10.1590/S1413-70542011000600001

Liu, H., Deng, R., Huang, C., Cheng, Z., \& Meng, H. (2019). Exogenous gibberellins alter morphology and nutritional traits of garlic (Allium sativum L.) bulb. Scientia Horticulturae, 246, 298-306. https://doi.org/ 10.1016/j.scienta.2018.11.003

Macêdo, F. S., Souza, R. J., \& Pereira, G. M. (2006). Controle de superbrotamento e produtividade de alho vernalizado sob estresse hídrico. Pesquisa Agropecuária Brasileira, 41, 629-635. https://doi.org/10.1590/ S0100-204X2006000400012 
Macêdo, F. S., Souza, R. J., Carvalho, J. G., Leite, L., \& Santos, B. R. (2009). Produtividade de alho vernalizado proveniente de cultura de meristemas em função de doses de nitrogênio e molibdênio. Bragantia, 68, 657-663. https://doi.org/10.1590/S0006-87052009000300012

Marouelli, W. A., Silva, W. L. C., Carrijo, O. A., \& Silva, H. R. (2002). Produção e qualidade de alho sob regimes de água no solo e doses de nitrogênio. Horticultura Brasileira, 20, 191-194. https://doi.org/ $10.1590 / \mathrm{S} 0102-05362002000300014$

Novo, M. C. S. S., \& Miranda Filho, H. S. (2006). Tuberização de dois cultivares de batata sob aplicação de sulfoniluréias. Planta Daninha, 24, 115-121. https://doi.org/10.1590/S0100-83582006000100015

Olesen, C. F., \& Cedergreen, N. (2010). Glyphosate uncouples gas exchange and chlorophyll fluorescence. Pest Manag Sci., 66, 536-542. https://doi.org/10.1002/ps.1904

Park, Y. B., \& Lee, B. Y. (1979). Study on the growth and bulb formation of garlic plants (Allium sativum L.). I. The effect of day-length on the bulb formation and secondary growth in 6 cloved garlic plants. Journal of the Korean Society for Horticultural Science, 20, 1-4.

Qaryouti, M. M., \& Kasrawi, M. A. (1995). Storage temperature of seed bulbs and planting date influence on garlic. I. Emergence, vegetative growth, bulbing and maturity. Advances in Horticultural Science, 9, 12-18.

Resende, F. V., Dusi, A. N., \& Melo, W. F. (2004). Recomendações básicas para a produção de alho em pequenas propriedades (p. 12). Brasília: EMBRAPA-CNPH.

Resende, G. M., Souza, R. J., Saggin Júnior, O. J., \& Flori, J. E. (2001). Produtividade e qualidade de bulbos de alho em diferentes doses de paclobutrazol e períodos de frigorificação. Ciência e Agrotecnologia, 25, 1343-1350.

Resende, J. T. V., Morales, R. G. F., Zanin, D. S., Resende, F. V., Paula, J. T., Dias, D. M., \& Galvão, A. G. (2013). Caracterização morfológica, produtividade e rendimento comercial de cultivares de alho. Horticultura Brasileira, 3, 157-162. https://doi.org/10.1590/S0102-05362013000100025

Salmazo, P. B. (2009). Efeitos de subdoses de sulfoniluréias na produtividade e qualidade de tubérculos de batata (Solanum tuberosum L.) (p. 93). Piracicaba: USP-ESALQ. https://doi.org/10.11606/D.11.2009. tde-14122009-155549

Souza, R. J., \& Casali, V. W. D. (1986). Pseudoperfilhamento: Uma anormalidade genético-fisiológica em alho. Informe Agropecuário, 12, 36-41.

Souza, R. J., \& Macêdo, F. S. (2009). Cultura do alho: Tecnologias modernas de produção (p. 181). Lavras: UFLA.

Taiz, L., Zeiger, E., Moller, I. M., \& Murphy A. (2017). Fisiologia e desenvolvimento vegetal (6th ed., p. 918). Porto Alegre, Artmed.

Trani, P. E., Camargo, M. S., Foltran, D. E., Hiroce, R., Arruda, F. B., \& Sawazaki, H. E. (2008). Produtividade e pseudoperfilhamento do alho influenciados pelo nitrogênio, potássio e cobertura morta. Horticultura Brasileira, 26, 330-334. https://doi.org/10.1590/S0102-05362008000300008

Velini, E. D., Alves, E., Godoy, M. C., Meschede, D. K., Souza, R. T., \& Duke, S. O. (2008). Glyphosate applied at low doses can stimulate plant growth. Pesticide Management Science, 64, 489-496. https://doi.org/ $10.1002 /$ ps. 1562

Vieira, R. L., Silva, A. L., Zaffari, G. R., \& Feltrim, A. L. (2014). In vitro morphogenesis of garlic plants: The role of growth regulators in bulb induction and development. Ciência Rural, 44, 439-435. https://doi.org/ 10.1590/S0103-84782014000300009

Wu, C., Wang, M., Dong, Y., Cheng, Z., \& Meng, H. (2015). Growth, bolting and yield of garlic (Allium sativum L.) in response to clove chilling treatment. Scientia Horticulturae, 194, 43-52. https://doi.org/10.1016/ j.scienta.2015.07.018

\section{Copyrights}

Copyright for this article is retained by the author(s), with first publication rights granted to the journal.

This is an open-access article distributed under the terms and conditions of the Creative Commons Attribution license (http://creativecommons.org/licenses/by/4.0/). 